University of Nebraska - Lincoln

DigitalCommons@University of Nebraska - Lincoln

Egyptian textiles and their production: 'word' and 'object'

Centre for Textile Research

$3-2-2020$

\title{
Egyptian pit-looms from the late first millennium $A D$ - attempts in reconstruction from the archaeological evidence
}

Johanna Sigl

German Archaeological Institute (DAI), Cairo

Follow this and additional works at: https://digitalcommons.unl.edu/egyptextiles

Part of the Africana Studies Commons, African Languages and Societies Commons, Classical Archaeology and Art History Commons, Fiber, Textile, and Weaving Arts Commons, History of Art, Architecture, and Archaeology Commons, and the History of Science, Technology, and Medicine Commons

Sigl, Johanna, "Egyptian pit-looms from the late first millennium AD - attempts in reconstruction from the archaeological evidence" (2020). Egyptian textiles and their production: 'word' and 'object'. 3.

https://digitalcommons.unl.edu/egyptextiles/3

This Article is brought to you for free and open access by the Centre for Textile Research at DigitalCommons@University of Nebraska - Lincoln. It has been accepted for inclusion in Egyptian textiles and their production: 'word' and 'object' by an authorized administrator of DigitalCommons@University of Nebraska - Lincoln. 


\title{
Egyptian pit-looms from the late first millennium AD - attempts in reconstruction from the archaeological evidence
}

\author{
Johanna Sigl
}

\section{Introduction}

In discussions on the development of weaving technology, specifically treadle looms in the Mediterranean area, Egypt is often referred to as one of the earliest countries in which people used foot-powered looms for producing cloth. It is thought to have been in regular use in the production of cloth as early as the second half of the $1^{\text {st }}$ millennium AD. ${ }^{1}$ This belief is built on results from excavations undertaken during the early $2 \mathrm{O}^{\text {th }}$ century by the Egypt Exploration Fund at the hill of Sheikh Abd el-Qurna in Luxor, ${ }^{2}$ as well as on textile studies. ${ }^{3}$ Unfortunately, none of the postulated looms has ever been found and no pictorial evidence has survived illustrating the apparatus that the weavers worked on. Texts provide only scant information, none of which is sufficiently descriptive. ${ }^{4}$ For the reconstruction of the weaving device used in Egypt during the Late Roman and Early Islamic periods one therefore depends on the scarce archaeological and architectural information from excavations. This consists predominantly of pits, ${ }^{5}$ which were identified by Herbert E. Winlock ${ }^{6}$ as substructures of a horizontal treadle loom. However, Winlock's identification was criticised by various researchers, ${ }^{7}$ and subsequently his suggestion was disproved by the experimental reconstruction of a loom within one of the pits of the monastery of Epiphanius, as well as the comparison with more recent archaeological evidence. ${ }^{8}$ Although Winlock was with much certainty correct in proposing that the pits were once loom emplacements, ${ }^{9}$ the type and features of the weaving apparatus are still uncertain.

Published in Maria Mossakowska-Gaubert, ed., Egyptian Textiles and Their Production: 'Word' and 'Object' (Hellenistic, Roman and Byzantine Periods) (Lincoln, NE: Zea Books, 2020). doi 10.32873/unl.dc.zea.1080

1. Zhao 2001, p. 213 following Carroll 1988, p. 37-38.

2. Winlock \& Crum 1926, p. 67-69.

3. E.g. Carroll 1985, p. 169-171.

4. E.g. Crum \& Evelyn White 1926, p. 247: no. 352

5. Few other parts of looms have been discovered, and even fewer in context with one of the pits in question. The finds excavated in close proximity to the pits are warp spacers (in the laura of Cyriacus, see Bechtold 2007, p. 56-57, or in Deir el-Bakhit, DB $2414+$ DB 2417 see in J. Sigl in Sigl \& Tatz in prep.), and weaving combs (in Deir el-Bakhit, DB 2700? and DB 298 see in J. Sigl in Sigl \& Tatz in prep.). However, these tools can be used in several types of weaving apparatus.

6. Winlock \& Crum 1926, p. 68.

7. White 1962, p. 173; Wild 1987, p. 459; el-Farag 1983, p. 54; Verhecken-Lammens \& de Jonghe 1993, p. 61; Huber 2006, p. 63, note 5 .

8. J. Sigl in Sigl \& Tatz in prep.

9. Apart from H.E. Winlock's loom emplacement hypothesis, which in its outlines is adopted here to similar longitudinal pits in the floors of the North Tombs of Tell el-Amarna, three other suggestions for the use of these installations were made independently: two by N. de Garis Davies (1903, p. 12-13 and note 1) and one by F. Kampp-Seyfried (1995, p. 214, note 28). All of them can be ruled out because of the triviality of their reasoning (Sigl 2008, p. 355-361; Sigl 2011, p. 19-20). 

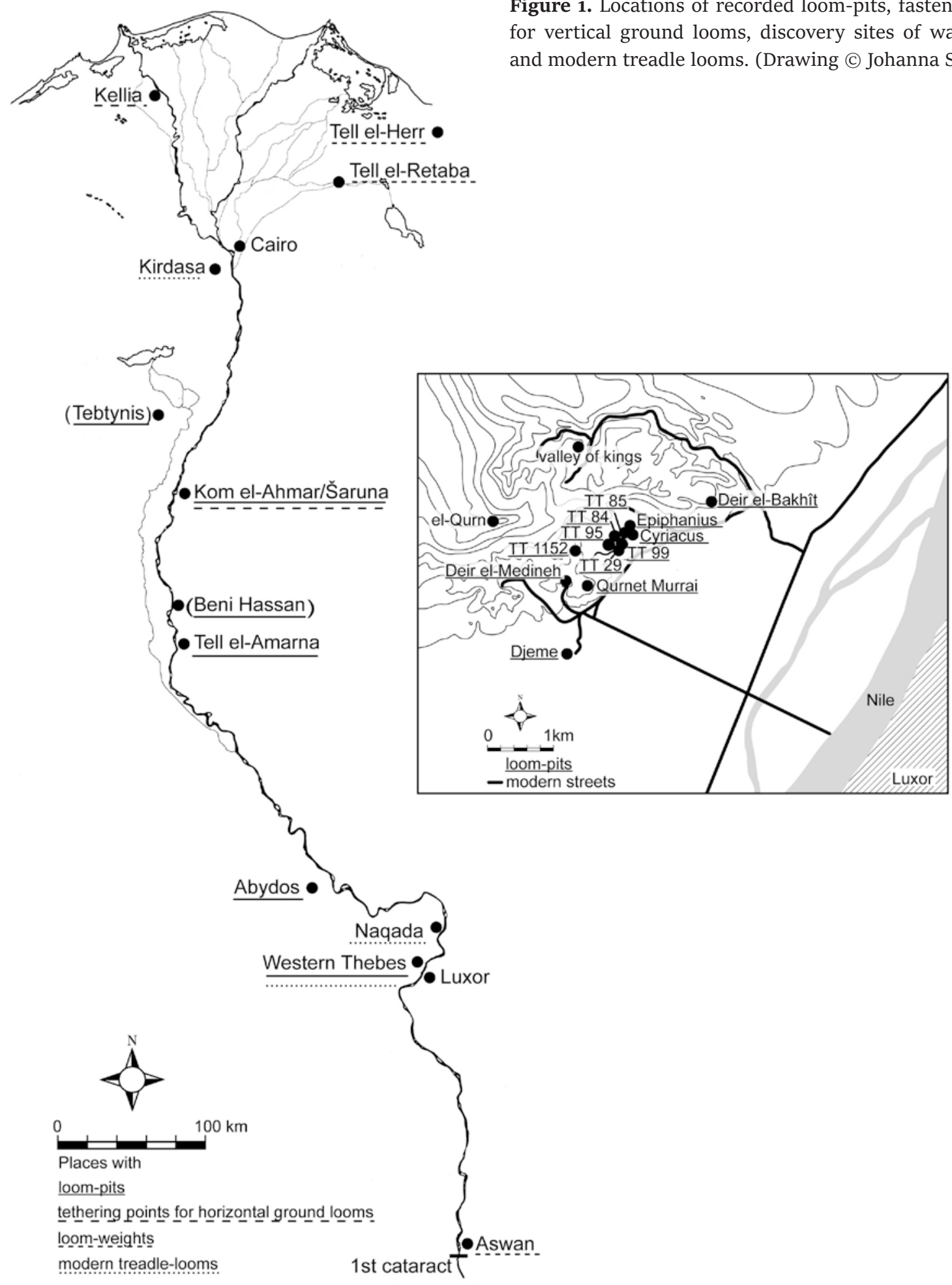

tethering points for horizontal ground looms

\section{loom-weights}

modern treadle-looms

J. Sigl, 2018
Figure 1. Locations of recorded loom-pits, fastening devices for vertical ground looms, discovery sites of warp-weights and modern treadle looms. (Drawing (c) Johanna Sigl, 2017).

\section{Loom-pits: the archaeological evidence}

The author has thus far been able to compile 53 examples of so-called loom-pits, all situated in Upper Egypt, mostly in Western Thebes (fig. 1). Eleven further structures (in Table marked with '??' in column 'no.') are mentioned in publications, where their existence could not be verified on plans, pictures or on site so far, and as such their 
identification in itself is not certain..$^{10}$ Otherwise, they have been found during excavations and look overall very similar to the pits in question, but differ in their chronological context and specific details. ${ }^{11}$ The precise dating of the securely identified features is difficult but can mostly be attributed to the re-use of Pharaonic structures in the late $1^{\text {st }}$ millennium AD. ${ }^{12}$ The overwhelming majority of cases suggest a Christian occupation with monastic activity taking place. Additionally, the pits display the following similarities (Table):

- no other part of the weaving instrument apart from the pit has survived to the present day; ${ }^{13}$

- all pits were set parallel to a wall ${ }^{14}$ - a fact N. de Garis Davies had already noted for the pits in the North Tombs at Tell el-Amarna; ${ }^{15}$

- their shape is longitudinal and their size exceeds 150 $\mathrm{cm}$ in length, in most cases; ${ }^{16}$
- in the best preserved examples, crossbars of wood were installed near either end and the bottom of the pit. In many of the less well-preserved examples the holes for their installation can still be seen.

There are only four types of loom that can be considered as once having been installed in the pits, primarily because they were either used in Egypt during earlier periods, or proposed to have been in use by the $1^{\text {st }}$ millennium AD: furthermore, because they are suitable for weaving cloth of the size for tunics or shrouds. ${ }^{17}$

The treadle loom has been suggested, as mentioned above, which was in use in China by the $2^{\text {nd }}$ century BC. ${ }^{18}$ However, it is not clear when it was introduced into the Mediterranean region. The first pictorial evidence of this kind of loom comes from Europe and dates to the $13^{\text {th }}$ century. ${ }^{19}$ Contemporary finds of early medieval pit treadle loom emplacements, ${ }^{20}$ which have been attested to $1^{\text {st }}$

10. In the publication of the monastery of Epiphanius, Winlock mentions eight pits, but only seven are depicted in his plans (Winlock \& Crum 1926, p. 67). In the contribution on the monastic structure of Qurnet Murai five pits are mentioned, but only three are distinguishable in the published plans, while the identification of the other three in the represented structures is uncertain (Castel 1991, p. 2042; J. Sigl in Sigl \& Tatz in prep.); in plans of the tombs BH 3 and BH 23 in Beni Hassan, structures might be identified as loom-pits, but an in situ verification is still to be done (J. Sigl in Sigl \& Tatz in prep.). In TT 84 a pit in the first hall of the tomb, directly left of the entrance, is too badly preserved into an older structure to be called a loom-pit (author's own observations with the kind permission of A. Gnirs-Loprieno and the local inspectors of her excavation project (2017); J. Sigl in Sigl \& Tatz in prep.); in the tombs at Kom el-Ahmar/Sharuna depressions were identified as feeding troughs, but could also be seen as crude loom-pits with 'crossbars' made of stone (J. Sigl in Sigl \& Tatz in prep.).

11. At the French excavations in Tebtynis several pits have been found that feature the same oblong shape, but the crossbar is inserted in additional depressions near each end and runs parallel to the length of the overall pit. Apart from this instance, these structures date to Ptolemaic times (information kindly provided by G. Hadji-Minaglou (2015 and 2018); J. Sigl in Sigl \& Tatz in prep.) and it is therefore uncertain if they are loom-pits at all.

12. For a discussion on the date of installation of the loom-pit in TT 99, see Strudwick 2011, p. 376-379. In Deir el-Bakhit the pits were put in place during the main occupation phase of the monastery during the $7^{\text {th }}$ to $9^{\text {th }}$ centuries AD (Beckh 2013, p. 55).

13. Only tools that could be used on any kind of loom were found. These are remains of warp spacers and weaving combs, spindles, needles, pin beaters, etc. (for example J. Sigl in Sigl \& Tatz in prep.; Huber 2006, p. 67; Huber 2007, p. 66-68).

14. There are a small number of exceptional cases: the pit in TT 95 was situated near a column, which in this case could have served the same purpose as a wall (cf. J. Sigl in Sigl \& Tatz in prep.); next to some of the pits in the monastery of Cyriacus round depressions in the floor could have served as fixtures for vertical beams, against which the loom could have leant (cf. Bechtold 2007, figs. 1, 4 and 5).

15. De Garis Davies 1903, p. 12.

16. Shorter examples are found at the monastery of Cyriacus (cf. Table; Bechtold 2007, figs. 1 and 4).

17. The use of these looms for keiriai, as Winlock suggested (Winlock \& Crum 1926, p. 68 and 71), is very unlikely, because it would not make economic sense to use such a wood and space-consuming apparatus for an item that can be woven on a small table loom.

18. Zhao 2001, p. 471-472, fig. 117.

19. Trinity College Museum 0.9.34 fol. 32 ${ }^{\text {b }}$, Cambridge, Great Britain (Carroll 1988, p. 34-36, fig. 10).

20. Windler 2008, p. 209-212. 
millennium AD contexts in Egypt, differ considerably from the installations discussed here. Today the standard type of pit treadle loom, which is known throughout the whole of North Africa, uses a similarly narrow roundish treadle emplacement to the medieval European one. ${ }^{21}$ There is no connection, either in time or location, to the pit-loom we are searching for. Furthermore, experimental reconstruction following the initial description of H.E. Winlock, and taking into account the construction of the mentioned modern pit-looms, proves that a foot-powered loom could not have been installed within the pits in question. ${ }^{22}$

\section{Weaving looms used in ancient Egypt: a typology ${ }^{23}$}

In Pharaonic Egypt weaving involved two kinds of looms. The older one is the horizontal ground loom, which is shown in both model form and in tomb paintings. ${ }^{24}$ Evidence for the use of this type of loom was found in Early Christian contexts at Kom el-Ahmar/Sharuna ${ }^{25}$ and in the hermitages of Kellia. ${ }^{26}$ Some of these constructions might have been used for mat weaving rather than cloth. ${ }^{27}$ On the other hand, looms similar to the ancient Egyptian types are still in use for textile weaving in Africa and the Near East, especially by nomadic groups. ${ }^{28}$ However, these s are never connected with any pit construction. They are therefore not the weaving devices we are searching for.

By the New Kingdom a vertical frame loom is depicted in tomb paintings instead of the ground loom. ${ }^{29}$ A quite complex reconstruction of this loom is given by Herbert G. Farbrother in Barry J. Kemp and Gillian Vogelsang-Eastwood's publication of the textile industry at Tell el-Amarna. ${ }^{30}$ Simpler kinds of vertical looms have been in use not only in ancient Greece and the Near East, but continue to be used up until the present day in the same areas as well as in many regions of Africa. ${ }^{31}$ In Syria/Palestine and amongst some African tribes a kind of vertical frame loom installed over an oblong pit is known..$^{32}$ Thus, this kind of weaving apparatus could be an answer to the question about the Egyptian pit-loom, an issue I will return to below.

After the $21^{\text {st }}$ Dynasty there are no further images of looms known from Egypt, however, at the same time the so called warp-weighted loom was in use in ancient Greece. In some cases the warp length was extended by standing the weaving apparatus over a pit. ${ }^{33}$ This type of loom was introduced during the Late Period into Egypt. Warp weights have been found at excavation sites that can

21. Examples from North and East Africa: Schädler 1987, p. 84, fig. 16 and p. 400-401, figs. 614-616; and the author's own observations in Egypt since 2005 (locations cf. fig. 1).

22. J. Sigl in Sigl \& Tatz in prep.

23. See also the article by Maria Mossakowska-Gaubert, in this volume (Mossakowska-Gaubert 2020).

24. For example: model from TT 280, Cairo JE 46723, Egypt, $3^{\text {rd }}$ millennium BC (Winlock 1955, p. 31-33, 88-89, pls. 25-27, 66, 67); wall painting in tomb of Khnumhotep II, Beni Hassan No. 3, Egypt, $2^{\text {nd }}$ millennium BC (Roth 1913, p. 3-7), etc.

25. Information kindly provided by B. Huber (2010). See as well Huber 2006, p. 63-64.

26. Long-bones of big mammals inserted in facing walls and building a rectangle: Qusur el Iseila: Hermitage no 14, room 11(?) and 16; Hermitage no 45, room 16 finale phase of $7^{\text {th }}$ century; Hermitage no 156, room 7 (Makowiecka 1986, p. 107-112; Makowiecka 1999, p. 26 and plan 1 fig. 2, plan 3 figs. 10 and 11, plan 4 figs. 19 and 20, plan 13 fig. 156, plan 14 fig. 168, plan 15 fig. 174, plan 24 figs. 422, 424 and 429, plan 25 fig. 439).

27. Makowiecka 1986, p. 107-112; Makowiecka 1999, p. 26.1

28. Schädler 1987, p. 56-65.

29. For example: wall painting in tomb of Thotnefer, TT 104, Egypt, $2^{\text {nd }}$ millennium BC (Shedid 1988, p. 128, pl. 5a, 27); talatatblock from Amarna, Malawi Museum, Egypt, $2^{\text {nd }}$ millennium BC (Messiha \& Elhitta 1979, p. 24, pl. XXXI: 586); etc.

30. Kemp \& Vogelsang-Eastwood 2001, p. 405-426.

31. For example: relief of Nerva, Rome, Italy, $1^{\text {st }}$ century AD (von Blanckenhagen 1940, p. 124, pls. 40-42); wall painting in the hypogeum of Aureli, Rome, Italy, $3^{\text {rd }}$ century AD (Himmelmann 1975, p. 22-23, pls. 6, 7); book painting, University of Utrecht 32 fol. 84b, Netherlands, $9^{\text {th }}$ century AD (Walton Rogers 2001, p. 164, fig. 19.5a); book painting from Eadwine or Cantabury, Trinity College Library R. 17.1 fol. 263, Cambridge, Great Britain, $12^{\text {th }}$ century AD (Walton Rogers 2001, p. 164, fig. 19.5b); modern looms: Schädler 1987, p. 65-70.

32. Syria/Palestine: Crowfoot 1941, p. 141-151; Stærmose Nielsen 1999, fig. 73B (my thanks to M. Mossakowska-Gaubert for pointing out the latter publication to me). Africa: Picton \& Mack 1979, figs. 41 and 60.

33. Depiction on an urn from Sopron (Ödenburg), Hungaria, Naturhistoric Museum, Vienna, Austria, $1^{\text {st }}$ century BC (Barber 1991, p. 55, 92, 106, figs. 2.15, 13.3); pits and loom-weights in palace of Tilleda, Germany, $10^{\text {th }}$ century AD (Grimm 1969 , p. 97-99, pl. 13). 


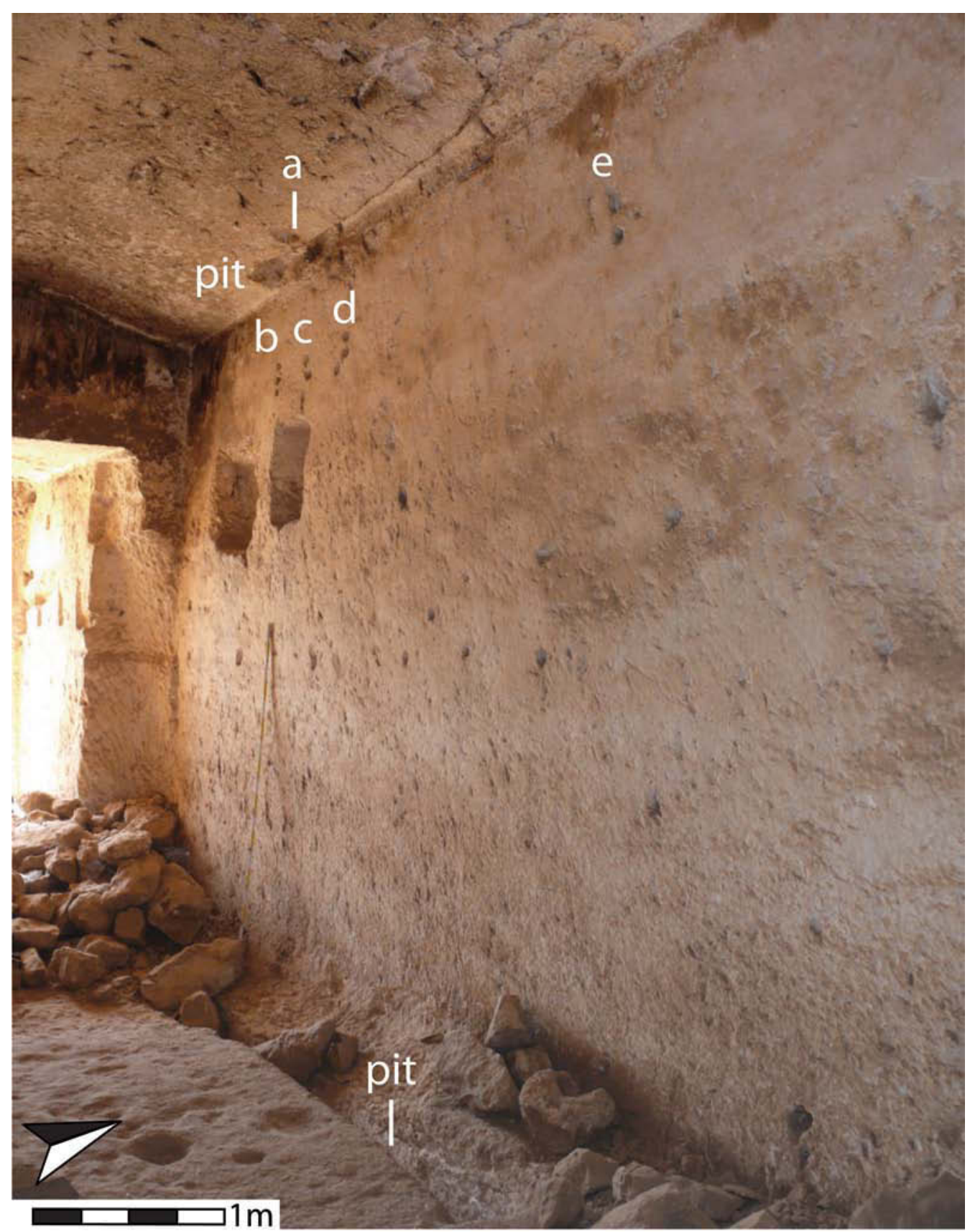

Figure 2. Pits in floor and ceiling, and tethering points in TA 3B, Tell elAmarna North Tombs. (Photo (C) Johanna Sigl, 2009).

be attested to military contexts or to the homes of foreigners living in Egypt. ${ }^{34}$ Not a single weight for weaving has been found in context with the type of pits under discussion in this article. Apart from this, the warp-weighted loom is usually associated with societies where wool is the dominant weaving fibre. Linen is, on the contrary, the dominant fibre in ancient Egypt. This material can only be woven on a warp-weighted loom with some difficulty because of its smooth surface. ${ }^{35}$ Despite the fact that wool was used a great deal in Egypt during the $1^{\text {st }}$ millennium $\mathrm{AD}$, this loom is in my opinion not the one we are searching for.

34. Warp-weights found in Tell el-Herr: Valbelle 1998, p. 809 and fig. 6. Warp-weights from Tell el-Retaba: Rzepka et al. 20o8, p. 134 and 138-140; Rzepka et al. 2010, p. 258 and 265-266; Warp-weights from the excavations in Syene/Aswan: Sigl 2017, p. 48, 129 and 145; information kindly provided by W. Müller (2010, 2013 and 2014); von Pilgrim et al. 2011, p. 137-140.

35. Tietzel 1988, p. 14 . 


\section{Pit-looms: attempts at reconstruction}

Therefore, the only loom that is left as a possible solution is the vertical frame loom. Important proof of vertically constructed weaving apparatuses first appeared during the study of two loom-pits located in the North Tombs at Tell el-Amarna, ${ }^{36}$ TA 3B (fig. 2) and TA 3C, thereafter from information provided by Nigel Strudwick ${ }^{37}$ on a pit in TT 99 in Western Thebes, and thirdly, from the most recent reevaluation of installations in TT 84 by Andrea Gnirs-Loprieno. ${ }^{38}$ These tombs not only contain pits in the floor, but grooves were also cut into the ceiling directly above pits at ground level (fig. 2). The side beams of the loom were most probably locked between the pits in the floor and the ceiling and the whole construction thus kept it from tilting. A tethering point in the rim of the upper pit in TA $3 \mathrm{~B}$ (fig. 2: a) might have been used to fix the whole apparatus or secure the upper weaving beam further. Additional hoops were found in the walls behind the pits in TA 3 B (fig. 2: b-e) and $3 \mathrm{C}$ (Table). As these anchor points (fig. 2: $\mathrm{b}$ and e) are in line with the ends of the pits carved into the floor and ceiling in both tombs, it is possible that the side beams of the loom had been fixed here as well. ${ }^{39}$ On the western side of $\mathrm{TA} 3 \mathrm{~B}$, three instead of one of the anchor points were recorded (fig. 2: b-d); could this be an indication that the left beam was moved for some reason, e.g. to weave smaller or wider cloth? Inside the pits no further sign was found that the side beam had been altered in its position. The additional hoops may also have had to be cut because the pit itself was extended towards the west when the loom no longer exceeded the requirements of the weaver. Unfortunately, both assumptions cannot be proven due to the poor state of preservation of the pits and no preserved cloth from the same context. Furthermore, in none of the other recorded examples are similar fixtures attested. In most cases no roof or walls of these rooms are preserved: the pit in the corner of the pillared hall of TT 85 was built underneath a natural hole in the ceiling of the tomb; ${ }^{\circ}$ the interior of TT $95^{41}$ is too poorly preserved to allow any useful information on any fixtures above ground level; in TA 1 the conservation work in the ceiling looks as if it would cover a groove at the edge of the eastern wall, but due to its filled in state it remains uncertain as to whether it really existed; all other examples are situated outside of former tombs and survive with no roof and only partly preserved walls (Table). On the other hand, in the Abydos pits, corbel blocks for square beams were installed over each of the small ends of the trenches (Table). ${ }^{42}$ The side-beams of a loom inserted into such mounts would have been held very tight, not allowing for any movement. These blocks could therefore be seen as a better version of the tethering points than TA $3 \mathrm{~B}$ and $3 \mathrm{C}$ in Amarna.

Apart from the clues mentioned above, there is further evidence for an argument that a vertical loom was in use. One major characteristic of the pits from Western Thebes (e.g. Deir el-Bakhit, Room 25, northern loom-pit: fig. 3) and Abydos were wooden crossbars fixed close to the bottom of the pit near each narrow end. In most cases the bars are not preserved, however, holes used to fix them in the sides of the pits can be attested (Table). In most loompits examined by the author, there is evidence that two bars had been installed, never one, and a single example of four bars can be seen in the case of loom-pit A from the monastery of Epiphanius. In some pits the bars were found in situ. ${ }^{43}$ Remains of rope were still wrapped around several of them ${ }^{44}$ and constriction marks led to the suggestion that a part of the loom had been firmly attached to the staffs. But the question remains as to which part? In a vertical frame it could have been the side beams, which were tied to the crossbars. The bars and ropes would have kept the loom frame steady, preventing reduction of the space between the side beams. ${ }^{45}$ The same function can be

36. Sigl 2011, p. 8 and 12.

37. Information kindly provided by N. Strudwick (2010); Strudwick 2011, p. 376-379.

38. Project Life Histories of Theban Tombs see https://htt.philhist.unibas.ch/ (last checked: 20/08/2017).

39. See modern fixation of side beams on a loom from Africa: Picton \& Mack 1979, fig. 2.

40. Author's own observation and information kindly provided by H. Heye (2005).

41. Information kindly provided by A. Gnirs-Loprieno (2005).

42. el-Farag 1983, figs. 1, 2, 3A and pl. 9: a and c.

43. E.g.: Monastery of Epiphanius, loom-pit A (Winlock \& Crum 1926, pl. XXI: B); Deir el-Bakhit, storage room, northern loompit (own observation); TT 85, forecourt, loom-pit near Coptic house, loom-pit next to tomb entrance (information kindly provided by H. Heye, 2004).

44. Sigl 2008, p. 361, fig. 2.

45. Examples that could disproof this theory are the mud floors of the pits in the monastery of Deir el-Bakhit which neither in the room 25 nor in room 44 show no abrasions, while at the same time such damages should be anticipated if a heavy object like a loom stood on them and even moved slightly during its use. On the other hand in some of the pits at Tell el-Amarna round or square depressions in the curves of the oblong pits seem to have been installed to hold in place a vertical positioned beam (cf. Sigl 2011, p. 16-17). 
suggested for tethering points found at the bottom of two pits in Kom el-Ahmar/Sharuna, formerly identified as feeding troughs (Table). ${ }^{46}$ These binding devices not only have nearly the same position in the pits as the crossbars, but would also be used to compensate for a higher amount of drag. ${ }^{47}$ However, since no sign of usage wear of the mud plastering around the crossbars in the pits, which were mud lined, could be observed, this solution remains questionable. Similarly the edges of the pit, where those side beams could have been placed following the example of the modern Syrian/Palestine looms, ${ }^{4}$ e.g. in the storage room in Deir el-Bakhit, do not show any signs of wear or destruction. Alternatively, one could suggest that the whole construction worked without side beams, but used a hanging upper weaving bar ${ }^{49}$ and a floating lower bar, between which the tension of the warp was adjusted by roping or releasing the binding of the lower beam down to the crossbars in the pits. ${ }^{\circ}$ This, however, would render the aforementioned ceiling pits in some of the tombs in Tell el-Amarna and at Sheikh Abd el-Qurna useless.

As mentioned above, a possible solution to the question about the late 1st millennium loom maybe the weaving apparatus from Syria and Palestine described by Grace M. Crowfoot. ${ }^{5^{1}}$ This vertical two-beam loom was also set up above a longitudinal pit in the floor. From photos in the publication, ${ }^{52}$ it looks like the loom's side beams stood on the floor next to the pit. The frame was leant in an angle against a wall or roof. The upper and lower weaving beams were fixed to the side beams and a third beam was set a certain distance behind the frame to elongate and tighten the warp. ${ }^{53}$ Could the tethering points in the walls of TA
3B (fig. 2: b-e) and $3 \mathrm{C}$ in Amarna have held such a third weaving beam? An argument against this possibility can be seen in the closeness of the installations to the walls, especially when taking into account the slightly angled position of a frame, when it was locked between the pits in floors and ceilings. Beams fastened to the hoops could in this case have been used to tighten the threads, but surely not to elongate them. A further counterargument is the high setting of the tethering points. If one follows the working method of the Syria/Palestine loom, the third beam has to be released at intervals to be able to move the warp around the loom. ${ }^{4}$ However, if the floor level in the tombs of Tell el-Amarna at the time when the weaver used it had been the same as in the Pharaonic period, he would have had to climb onto something to perform this task making the procedure a great deal more difficult. The first interpretation, where the tethering points are used as a means to fix the side beams, therefore, seems more suitable given the present state of knowledge.

The way in which the warp was guided around the weaving beams might furthermore be used as an indicator for the loom. In Crowfoot's Syria/Palestine examples, the warping is tubular with a turning rod.55 Thus, when the cloth is finished, the turning rod can be removed and the start and end border of the cloth will show loops where it once fitted. However, such loops could not be identified in the few samples of cloth that had been sufficiently preserved from Deir el-Bakhit. On the contrary, the scarce examples of visible cloth endings showed open fringe threads. ${ }^{56}$ It is therefore more likely that weaving took place on one plane only. ${ }^{57}$

46. Schenkel \& Gomaà 2004, pls. 156: a, 157: a, and 158: c.

47. Why three such bails had been installed in one of the troughs (Table) cannot be answered. It may have been used as an extra means to fix the loom, also at its lower weaving beam.

48. Crowfoot 1941, pl. XII, 1 and XIII.

49. E.g. see modern looms from Africa: Broudy 1993, figs. 3-25; Schädler 1987, figs. 86-88.

50. Similar to looms from Gabun or Tandjua, Lac Mai-Ndombe, depicted by K.-F. Schädler (1987, p. 67, fig. 12 and p. 69, fig. 80).

51. Crowfoot 1941, p. 141-151; Chr. Verhecken-Lammens and D. de Jonghe also suggested a vertical two-beam loom to be the apparatus on which a child's tunic they studied had been woven: Verhecken-Lammens \& de Jonghe 1993 , p. 61.

52. Crowfoot 1941, pl. XIII.

53. Ibid., p. 142.

54. Loc. cit.

55. Ibid., p. 142-143.

56. S. Tatz in Sigl \& Tatz in prep.

57. Of course, the loops could have been cut open as well or the warp was wrapped tubularly without a turning rod (see Kemp \& Vogelsang-Eastwood 2001, fig. 9.4a-d). See a parallel for a possible pit-loom with weaving done on one plane only: Picton \& Mack 1979, figs. 54-56. 


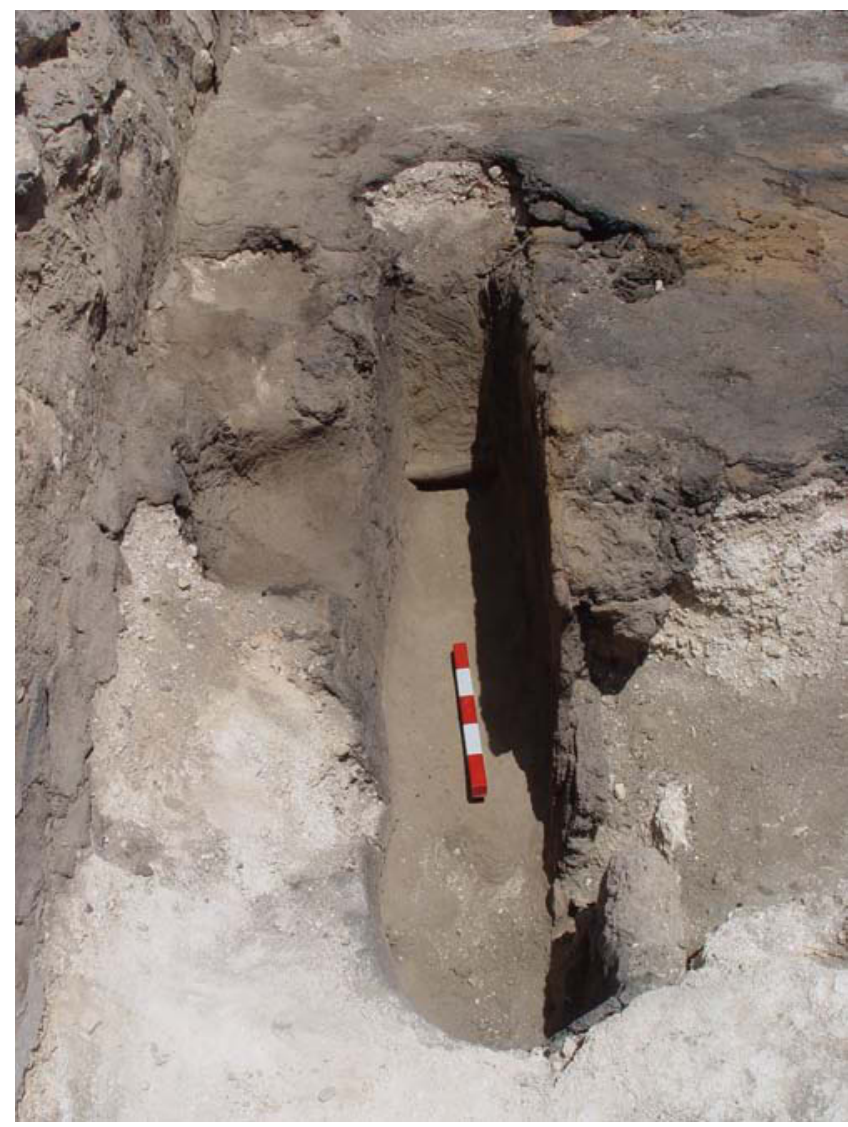

Figure 3. The northern loom-pit of Room 25 in Deir el-Bakhit with a seat for a single person on the northern (left) side and one in situ crossbar at the eastern (far) end of the pit. (Photo: Ina Eichner (C) DAI Cairo / LMU Munich, 2005).

Aside from what has been considered thus far, not every single pit might have held the same type of loom, and the position of the weaver is one of the best indicators for this point. While this loom is definitely close to a wall and could either seat one (fig. 3) or more persons (fig. 4) in the case of the loom-pits at Deir el-Bakhit, ${ }^{8}$ there is not enough space to seat the weaver(s) between wall and trenches in the cases of TA $3 \mathrm{~B}$ (fig. 2), 3C, and in TT 84, TT 99 (Table). Unfortunately, an installation indicating the seat of the weaver can be reconstructed in only a few cases. Features such as an extension on the side across from the wall in the pit in the forecourt of TT 29 cannot as yet be fully explained.

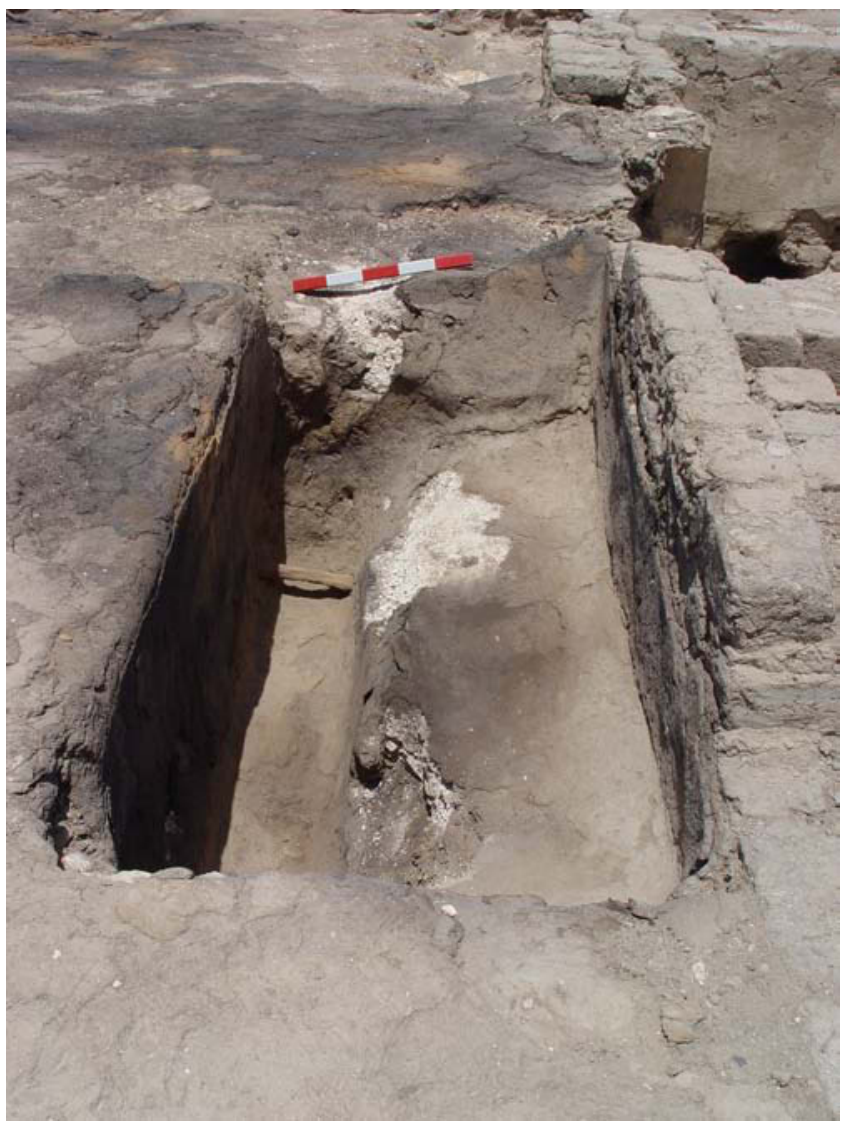

Figure 4. The eastern loom-pit of Room 25 in Deir el-Bakhit with a seat for more than one person on the eastern (right) side and one in situ crossbar at the northern (far) end of the pit. (Photo: Ina Eichner (C) DAI Cairo / LMU Munich, 2005).

\section{Final remarks}

In summary, the actual loom, which had once been set up in the longitudinal pits recorded in Western Thebes, Abydos, Tell el-Amarna, Kom el-Ahmar/Sharuna and possibly in Beni Hassan and Tebtynis, will remain the object of much speculation due to the low state of preservation. The loom from Syria/Palestine described above might not be the exact parallel, but at the moment it seems to be the closest possible solution. As mentioned, various kinds of construction, for example an alteration between floating beams and a strong frame construction might also be possible. Only with the recording of additional examples of these pits and of the surrounding archaeological remains of the late $1^{\text {st }}$ millennium $\mathrm{AD}$, amongst which actual parts of the loom might be found, is there any possibility of answering the riddle of the pit-loom used in Egypt. 
Table: Loom-pits collected by the author since 2005 ( 1 = length ( $\min .-$ max.); $\mathbf{w}=$ width (min. - max.); $\mathbf{d}=$ preserved depth (min. -max.); cb. = cross-bar; cbh.= crossbar holes (in pairs); tb.= tethering point; $\mathbf{c s .}$ = corbel stone for beam(?); $\mathbf{c p} .=$ ceiling pit; $\mathbf{N}=$ north; $\mathbf{E}$ = east, $\mathbf{S}$ = south, $\mathbf{W}$ = west; ? = no data available; ?? = uncertain identification)

- $\quad$ Deir el-Bachît: author's own observations (2005-2006); Sigl 2007; Eichner et al. 2009; Sigl 2016; J. Sigl in Sigl \& Tatz in prep.

- $\quad$ Monastery of Epiphanius: Winlock \& Crum 1926, p. 68-71; J. Sigl in Sigl \&Tatz in prep. Revised seat-position for the loom-pit in cell A near entrance, E side: seat = Winlock \& Crum 1926; seat = J. Sigl 2010: because of the similarity to the seat-installations in Deir el-Bakhit.

- $\quad$ Laura of Cyriacus: Winlock \& Crum 1926, p. 68-71; J. Sigl in Sigl \& Tatz in prep.; Bács, 200o; Bechtold 2007.

- $\quad$ Qurnet Murrai: Castel 1979; Castel 1991; J. Sigl in Sigl \& Tatz in prep.

- $\quad$ Deir el-Medineh: Bruyère 1948, p. 48, pl. 6; J. Sigl in Sigl \& Tatz in prep.

- $\quad$ TT 29: Information provided by L. Bavay (2005-2006); Tefnin 2002; Boud'hors \& Heurtel 2002; Bavay (2007-2008; J. Sigl in Sigl \& Tatz in prep.

- $\quad$ TT 84: Information provided by E. Grothe (2005) and A. Gnirs-Loprieno (2017); Gnirs et al. 1997; J. Sigl in Sigl \& Tatz in prep.

- $\quad$ TT 85: Information provided by H. Heye (2005); Gnirs et al. 1997; J. Sigl in Sigl \& Tatz in prep.

- TT 95: Information provided by A. Gnirs-Loprieno (2005); Gnirs et al. 1997; J. Sigl in Sigl \& Tatz in prep.

- $\quad$ TT 99: Information provided by N. Strudwick (2010); Strudwick 2011; J. Sigl in Sigl/Tatz in prep.

- $\quad$ TT 1152: Information provided by I. Antoniak (2005); Author's own observations (2005); Górecki 2013, p. 185; J. Sigl in Sigl \& Tatz in prep.

- $\quad$ Medinet Habu/Djeme: Hölscher 1934, pl. 34: I4; Hölscher 1954, p. 57-61, figs. 6o-61; J. Sigl in Sigl \& Tatz in prep.

- $\quad$ 'Weaving factory'/monastery of Mousa: identification of the building complex by Ayman Mohamed Damarany, 19.02.2014, Tell!-lecture series at German Archaeological Institute Cairo; el-Farag 1983; J. Sigl in Sigl \& Tatz in prep.

- $\quad$ TA 1: de Garis Davies 1905b, pl. I.; Sigl 2011, p. 360-362; J. Sigl in Sigl \& Tatz in prep.

- $\quad$ TA 2: de Garis Davies 1905a, p. 33, pl. XXVIII; Sigl 2011, p. 362; J. Sigl in Sigl \& Tatz in prep.

- $\quad$ TA 3B: de Garis Davies 1905a, p. 3, pl. XLIV; Sigl 2011, p. 363-365; J. Sigl in Sigl \& Tatz in prep.

- $\quad$ TA 3C: de Garis Davies 1905a, p. 3-4, pl. XLIII; Sigl 2011, p. 366-368; J. Sigl in Sigl \& Tatz in prep.

- $\quad$ TA 3: Sigl 2011, p. 368-370; J. Sigl in Sigl \& Tatz in prep.

- $\quad$ TA 4: de Garis Davies 1903, p. 12-13, pl. I; Sigl 2011, p. 370-373; J. Sigl in Sigl \& Tatz in prep.

- $\quad$ TA 5: de Garis Davies 1906, pl. I; Sigl 2011, p. 373-374; J. Sigl in Sigl \& Tatz in prep.

- $\quad$ BH 3: Newberry \& Fraser 1893b, pl. XXII: plan: shaft B and cross-section A-B plus pl. XXIII: fig. 2; J. Sigl in Sigl \& Tatz in prep.

- $\quad$ BH 23: Newberry \& Fraser 1893a, pl. XXIII: plan: close to N wall of chamber; J. Sigl in Sigl/Tatz in prep.

- $\quad$ Deir el-Qarabin: Information provided by B. Huber (2010); Huber 2006, p. 63-64; Huber 2007, p. 66-68; J. Sigl in Sigl \& Tatz in prep.

- V23: Schenkel \& Gomaà, 2004, Pl. 156: a (two structures in room in northeastern edge of forecourt), 157: a (in the foreground), 158: c.

- $\quad$ Umm el-Breigât (Tebtynis): Information provided by G. Hadji-Minaglou (2015 and 2018); J. Sigl in Sigl \& Tatz in prep.

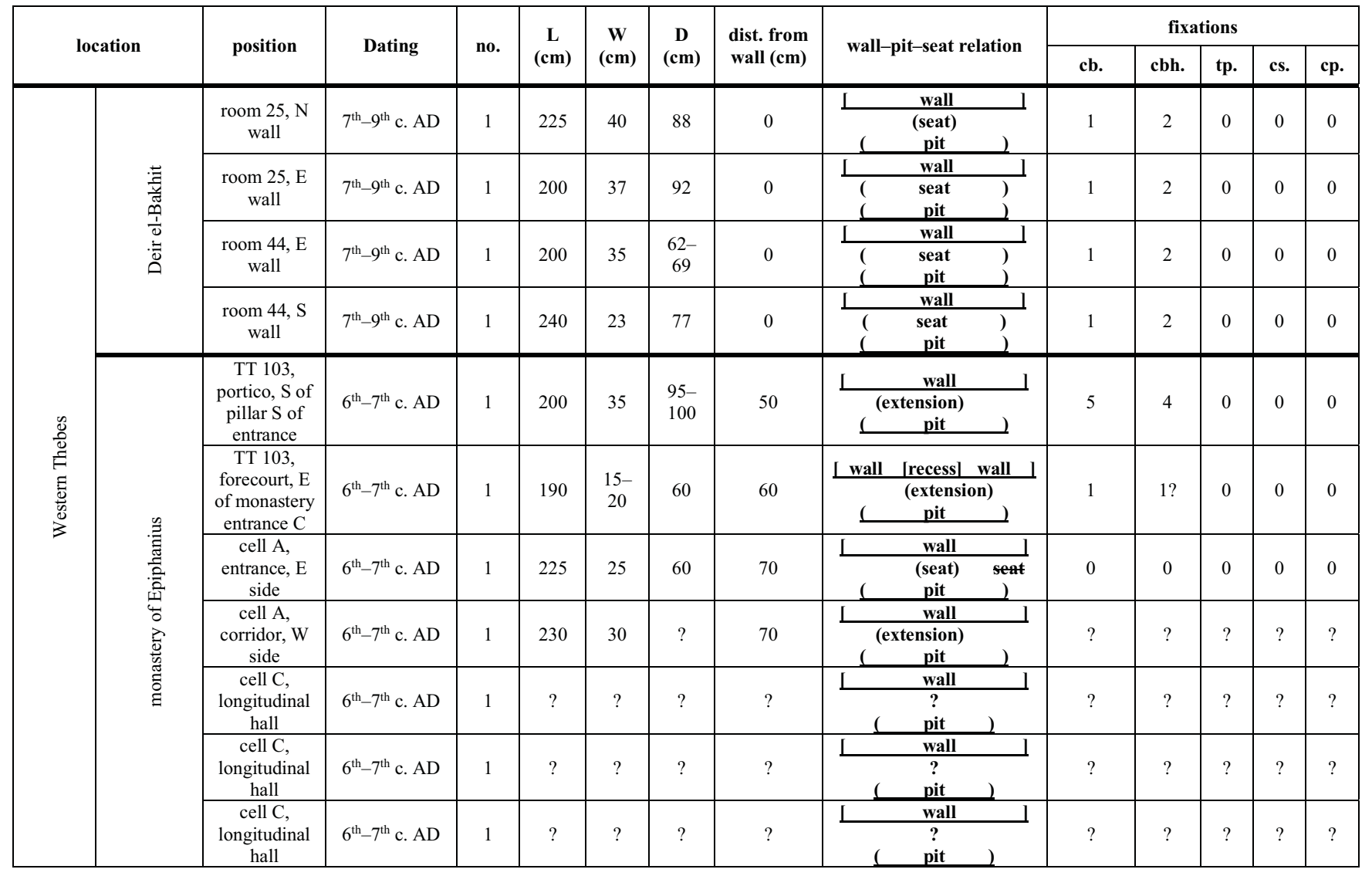




\begin{tabular}{|c|c|c|c|c|c|c|c|c|c|c|c|c|c|}
\hline \multirow{2}{*}{ location } & \multirow{2}{*}{ position } & \multirow{2}{*}{ Dating } & \multirow{2}{*}{ no. } & \multirow{2}{*}{$\begin{array}{c}\mathrm{L} \\
(\mathrm{cm})\end{array}$} & \multirow{2}{*}{$\begin{array}{c}\mathrm{W} \\
(\mathrm{cm})\end{array}$} & \multirow{2}{*}{$\begin{array}{c}\mathrm{D} \\
(\mathrm{cm})\end{array}$} & \multirow{2}{*}{$\begin{array}{l}\text { dist. from } \\
\text { wall }(\mathrm{cm})\end{array}$} & \multirow{2}{*}{ wall-pit-seat relation } & \multicolumn{5}{|c|}{ fixations } \\
\hline & & & & & & & & & cb. & cbh. & tp. & es. & cp. \\
\hline \multirow{7}{*}{ 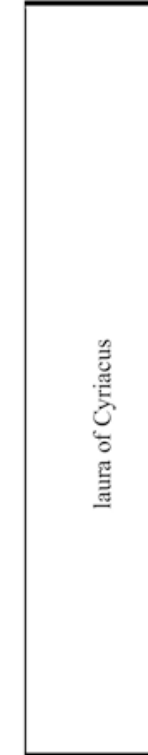 } & $\begin{array}{c}\text { ?? } \\
\text { (=TT65, near } \\
\text { Paser-wall?) }\end{array}$ & $6^{\text {th }}-7^{\text {th }}$ c. AD & $1 ? ?$ & $?$ & $?$ & $?$ & $?$ & $?$ & $?$ & $?$ & $?$ & $?$ & $?$ \\
\hline & $\begin{array}{l}\text { TT } 65 \text {, near } \\
\text { Paser-wall }\end{array}$ & $6^{\text {th }}-7^{\text {th }}$ c. AD & 1 & 187 & 43 & 40 & $?$ & $\begin{array}{c}\text { wall } \\
\text { seat? } \\
\text { (extension) } \\
(\text { pit } \\
\end{array}$ & 1 & $?$ & 0 & 0 & 0 \\
\hline & $\begin{array}{l}\text { TT } 65 \text {, } \\
\text { forecourt }\end{array}$ & $6^{\text {th }}-7^{\text {th }}$ c. AD & 1 & 150 & 45 & 10 & $?$ & $\begin{array}{l}\text { no walls in vicinity; no } \\
\text { seat discernible }\end{array}$ & 0 & 0 & 0 & 0 & 0 \\
\hline & $\begin{array}{l}\text { TT } 65 \text {, } \\
\text { forecourt }\end{array}$ & 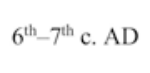 & 1 & 140 & 45 & 25 & $?$ & $\begin{array}{l}\text { no walls in vicinity; no } \\
\text { seat discernible }\end{array}$ & 1 & $?$ & 0 & 0 & 0 \\
\hline & $\begin{array}{l}\text { TT-NN-24, } \\
\text { forecourt, S } \\
\text { of oven }\end{array}$ & $6^{\text {th }}-7^{\text {th }}$ c. AD & 1 & 110 & $\begin{array}{c}30- \\
55\end{array}$ & 80 & $?$ & $\begin{array}{l}\text { no walls in vicinity; no } \\
\text { seat discernible }\end{array}$ & 0 & 0 & 0 & 0 & 0 \\
\hline & $\begin{array}{l}\text { TT-NN-24, } \\
\text { forecourt, } \\
\text { near above } \\
\text { mentioned } \\
\text { one }\end{array}$ & 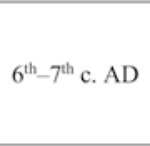 & 1 & 110 & $\begin{array}{c}30- \\
55\end{array}$ & 80 & $?$ & $\begin{array}{l}\text { no walls in vicinity; no } \\
\text { seat discernible }\end{array}$ & 0 & 0 & 0 & 0 & 0 \\
\hline & $\begin{array}{l}\text { TT-NN-24, } \\
\text { forecourt, } \\
\text { near above } \\
\text { mentioned } \\
\text { one } \\
\end{array}$ & $6^{\text {th }}-7^{\text {th }}$ c. $\mathrm{AD}$ & 1 & 100 & 35 & 50 & $?$ & $\begin{array}{l}\text { no walls in vicinity; no } \\
\text { seat discernible }\end{array}$ & 0 & 0 & 0 & 0 & 0 \\
\hline $\begin{array}{l}\text { 용 } \\
\text { 豆 }\end{array}$ & $\begin{array}{c}\text { forecourt, } \\
\text { middle, near } \\
\text { 'Coptic } \\
\text { wall'- } \\
\text { remains } \\
\end{array}$ & $8^{\text {th }}$ c. AD & 1 & 176 & 24 & 87 & 0 & $L \frac{\text { wall }}{\left(\begin{array}{c}\text { pit } \\
\text { (extension) }\end{array}\right)}$ & 1 & 1 & 0 & 0 & 0 \\
\hline \multirow{3}{*}{$\begin{array}{l}\varpi \\
⿱ ⺊ 尸 \\
\models\end{array}$} & $\begin{array}{l}\text { forecourt, S } \\
\text { half }\end{array}$ & $\begin{array}{l}1^{\text {st }} \text { mill. AD: } \\
\text { Christian }\end{array}$ & 1 & 155 & 32 & 50 & $?$ & $\begin{array}{l}\text { no walls in vicinity; no } \\
\text { seat discernible }\end{array}$ & 1 & 2 & 0 & 0 & 0 \\
\hline & $\begin{array}{c}\text { first hall, } \mathrm{N} \\
\text { of entrance } \\
\text { to second } \\
\text { hall } \\
\end{array}$ & $\begin{array}{l}1^{\text {st }} \text { mill. AD: } \\
\text { Christian }\end{array}$ & 1 & 200 & $>20$ & 50 & 40 & $\begin{array}{c}\text { wall } \\
\text { (shaft) } \\
\text { pit } \\
\text { (shaft) }\end{array}$ & 1 & 1 & 0 & 0 & 1 \\
\hline & $\begin{array}{l}\text { first hall, S } \\
\text { of tomb } \\
\text { entrance }\end{array}$ & $\begin{array}{l}1^{\text {st }} \text { mill. AD: } \\
\text { Christian? }\end{array}$ & $1 ? ?$ & 200 & $?$ & 20 & $?$ & $\begin{array}{c}\text { wall } \\
\text { (extension) } \\
\left(\begin{array}{c}\text { pit } \\
(\text { extension })\end{array}\right)\end{array}$ & 0 & 0 & 0 & 0 & $1 ?$ \\
\hline \multirow{5}{*}{$\begin{array}{l}\mathscr{\infty} \\
\mathfrak{H}\end{array}$} & $\begin{array}{l}\text { pillar hall, } \\
\text { SW edge, S } \\
\text { wall }\end{array}$ & $\begin{array}{l}\text { 1st mill. AD: } \\
\text { Christian }\end{array}$ & 1 & 180 & $\begin{array}{c}20- \\
36\end{array}$ & $>14$ & $35-40$ & $\begin{array}{c}\text { wall } \\
\frac{(\text { pit }}{?}\end{array}$ & 1 & 1 & 0 & 0 & 0 \\
\hline & $\begin{array}{l}\text { forecourt, } \\
\text { outside of } \\
\text { 'Coptic } \\
\text { building', E } \\
\text { wall } \\
\end{array}$ & $\begin{array}{l}\text { 1st mill. AD: } \\
\text { Christian }\end{array}$ & 1 & 190 & 36 & 50 & 0 & $\frac{\text { wall }}{\frac{\text { pit }}{?}}$ & 1 & 1 & 0 & 0 & 0 \\
\hline & $\begin{array}{l}\text { forecourt, W } \\
\text { half, near } \\
\text { entrance, } \mathrm{S} \\
\text { wall }\end{array}$ & $\begin{array}{l}\text { 1st mill. AD: } \\
\text { Christian }\end{array}$ & 1 & 228 & $\begin{array}{c}52- \\
58\end{array}$ & 40 & 0 & $\left.\frac{\text { wall }}{\text { Lit }}\right]$ & 2 & 2 & 0 & 0 & 0 \\
\hline & $\begin{array}{c}\text { forecourt, } \\
\text { SW edge, } \mathrm{S} \\
\text { wall } \\
\end{array}$ & $\begin{array}{l}\text { 1st mill. AD: } \\
\text { Christian }\end{array}$ & 1 & $?$ & $?$ & $\begin{array}{c}30- \\
45\end{array}$ & 0 & $\begin{array}{c}\text { wall } \\
\frac{(\text { pit }}{?}\end{array}$ & 1 & 0 & 0 & 0 & 0 \\
\hline & $\begin{array}{c}\text { forecourt, } \mathrm{S} \\
\text { half of } \mathrm{W} \\
\text { wall }\end{array}$ & $\begin{array}{l}\text { 1st mill. AD: } \\
\text { Christian }\end{array}$ & 1 & $?$ & 25 & $?$ & 30 & \begin{tabular}{|c|} 
wall \\
$\frac{\text { pit }}{?}$
\end{tabular} & 0 & 0 & 0 & 0 & 0 \\
\hline $\begin{array}{l}\curvearrowleft \\
\stackrel{\bullet}{E}\end{array}$ & $\begin{array}{l}\text { pillar-hall, } \\
\text { near wall } \\
\text { remains near } \\
\text { pillar H }\end{array}$ & $\begin{array}{l}\text { 1st mill. AD: } \\
\text { Christian }\end{array}$ & 1 & 176 & 26 & 39 & $?$ & $\begin{array}{l}\text { no walls in vicinity; no } \\
\text { seat discernible }\end{array}$ & 1 & 1 & 0 & 0 & 0 \\
\hline $\begin{array}{l}\text { ฉ̀ } \\
\qquad\end{array}$ & $\begin{array}{c}\text { first hall, } \mathrm{N} \\
\text { of entrance } \\
\text { to second } \\
\text { hall }\end{array}$ & $?$ & 1 & 250 & 60 & 15 & 0 & $\frac{L \text { wall }}{\frac{\text { pit }}{?}}$ & 0 & 0 & 0 & 0 & 1 \\
\hline
\end{tabular}




\begin{tabular}{|c|c|c|c|c|c|c|c|c|c|c|c|c|c|c|}
\hline \multirow{2}{*}{\multicolumn{2}{|c|}{ location }} & \multirow{2}{*}{ position } & \multirow{2}{*}{ Dating } & \multirow{2}{*}{ no. } & \multirow{2}{*}{$\begin{array}{c}\mathbf{L} \\
(\mathrm{cm})\end{array}$} & \multirow{2}{*}{$\underset{(\mathrm{cm})}{\mathrm{W}}$} & \multirow{2}{*}{$\begin{array}{c}\text { D } \\
\text { (cm) }\end{array}$} & \multirow{2}{*}{$\begin{array}{l}\text { dist. from } \\
\text { wall (cm) }\end{array}$} & \multirow{2}{*}{ wall-pit-seat relation } & \multicolumn{5}{|c|}{ fixations } \\
\hline & & & & & & & & & & , & e & & 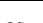 & 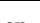 \\
\hline & \multirow{2}{*}{ 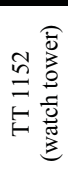 } & $\begin{array}{l}\text { forecourt, } \mathrm{W} \\
\text { half, } \mathrm{N} \text { wall }\end{array}$ & 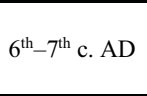 & 1 & ? & $<20$ & $?$ & $?$ & $\begin{array}{c}\text { wall } \\
\frac{\text { pit }}{?}\end{array}$ & 2 & 2 & 0 & 0 & 0 \\
\hline & & $?$ & $6^{\text {th }}-7^{\text {th }}$ c. AD & 1 & $?$ & $?$ & $?$ & $?$ & $?$ & $?$ & $?$ & $?$ & $?$ & $?$ \\
\hline & \multirow{6}{*}{ 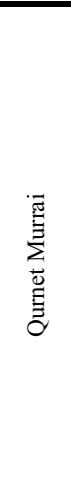 } & $\begin{array}{c}\text { working } \\
\text { room, S wall }\end{array}$ & $6^{\text {th }-8^{\text {th }}} \mathrm{c} . \mathrm{AD}$ & 1 & 180 & 30 & ? & 30 & 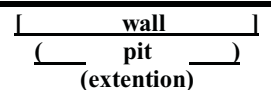 & 2 & 2 & $?$ & $?$ & $?$ \\
\hline & & $\begin{array}{l}\text { working } \\
\text { room, W } \\
\text { wall }\end{array}$ & $6^{\text {th }-8^{\text {th }}} \mathrm{c} . \mathrm{AD}$ & 1 & 140 & 30 & $?$ & 30 & $\begin{array}{c}\frac{\text { wall }}{\text { pit }} \\
?\end{array}$ & 2 & 2 & $?$ & $?$ & $?$ \\
\hline & & $\begin{array}{c}\text { working } \\
\text { room, } \mathrm{N} \text { wall }\end{array}$ & $6^{\text {th }-8^{\text {th }}} \mathrm{c} . \mathrm{AD}$ & 1 & 210 & 40 & $?$ & 30 & $\begin{array}{l}\left.L \frac{\text { wall }}{\text { pit }}\right) \\
\frac{?}{?}\end{array}$ & 1 & 1 & $?$ & $?$ & $?$ \\
\hline & & $\begin{array}{l}\text { SE cell, W } \\
\text { wall }\end{array}$ & $6^{\text {th }-8^{\text {th }}} \mathrm{c} . \mathrm{AD}$ & 1 & 200 & 45 & $?$ & 60 & $\begin{array}{cc}\text { wall } \\
\\
\left(\begin{array}{c}\text { pit?? } \\
(\end{array}\right) \\
\end{array}$ & 1 & 1 & $?$ & $?$ & ? \\
\hline & & $\begin{array}{c}? \\
\text { (corridor, } \mathrm{N} \\
\text { wall) }\end{array}$ & $6^{\text {th }-8^{\text {th }}} \mathrm{c} . \mathrm{AD}$ & 1?? & $230 ?$ & $20 ?$ & $?$ & $30 ?$ & $\begin{array}{c}\text { wall } \\
\text { (extension?? ) } \\
\text { pit?? } \\
\end{array}$ & $?$ & $?$ & $?$ & $?$ & $?$ \\
\hline & & ? & $6^{\text {th }}-8^{\text {th }}$ c. AD & $1 ? ?$ & $?$ & $?$ & $?$ & $?$ & $?$ & $?$ & $?$ & $?$ & $?$ & $?$ \\
\hline & 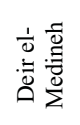 & $\begin{array}{c}\text { 'Coptic } \\
\text { structure’ W } \\
\text { of temple, E } \\
\text { wall }\end{array}$ & $\begin{array}{l}\text { 1st mill. AD: } \\
\text { Christian }\end{array}$ & 1 & 220 & 40 & $?$ & 0 & $\frac{L \text { wall }}{\frac{\text { pit }}{?}}$ & 2 & 2 & $?$ & $?$ & $?$ \\
\hline \multirow{8}{*}{ 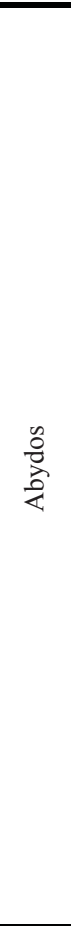 } & \multirow{8}{*}{ 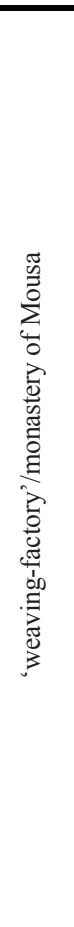 } & $\begin{array}{l}\text { great pillar } \\
\text { room, W half } \\
\text { of } \mathrm{N} \text { wall }\end{array}$ & $7^{\text {th }}-8^{\text {th }}$ c. AD & 1 & 165 & $\begin{array}{l}90 \\
\text { incl. } \\
\text { ext. }\end{array}$ & 330 & 0 & 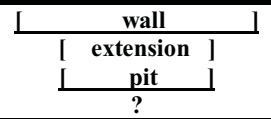 & 0 & 2 & 0 & $?$ & 0 \\
\hline & & $\begin{array}{l}\text { great pillar } \\
\text { room, E half } \\
\text { of N wall }\end{array}$ & $7^{\text {th }}-8^{\text {th }}$ c. AD & 1 & 165 & $\begin{array}{l}90 \\
\text { incl. } \\
\text { ext. }\end{array}$ & 330 & 0 & $\begin{array}{c}\text { wall } \\
{\left[\begin{array}{c}\text { extension } \\
\text { pit } \\
\text { ? }\end{array}\right]} \\
\end{array}$ & 0 & 2 & 0 & 1 & 0 \\
\hline & & $\begin{array}{l}\text { great pillar } \\
\text { room, N half } \\
\text { of E wall }\end{array}$ & $7^{\text {th }}-8^{\text {th }}$ c. AD & 1 & 165 & $\begin{array}{l}90 \\
\text { incl. } \\
\text { ext. }\end{array}$ & 330 & 0 & 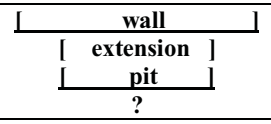 & 0 & 2 & 0 & 2 & 0 \\
\hline & & $\begin{array}{l}\text { great pillar } \\
\text { room, S half } \\
\text { of E wall }\end{array}$ & $7^{\text {th }}-8^{\text {th }}$ c. AD & 1 & 165 & $\begin{array}{l}90 \\
\text { incl. } \\
\text { ext. }\end{array}$ & 330 & 0 & 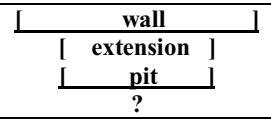 & 0 & 2 & 0 & $?$ & 0 \\
\hline & & $\begin{array}{l}\text { great pillar } \\
\text { room, E half } \\
\text { of S wall }\end{array}$ & $7^{\text {th }}-8^{\text {th }}$ c. AD & 1 & 165 & $\begin{array}{l}90 \\
\text { incl. } \\
\text { ext. }\end{array}$ & 330 & 0 & $\begin{array}{c}\text { wall } \\
{\left[\begin{array}{c}\text { extension } \\
\text { pit }\end{array}\right]} \\
?\end{array}$ & 0 & 2 & 0 & 2 & 0 \\
\hline & & $\begin{array}{l}\text { great pillar } \\
\text { room, W half } \\
\text { of S wall }\end{array}$ & $7^{\text {th }}-8^{\text {th }}$ c. AD & 1 & 165 & $\begin{array}{l}90 \\
\text { incl. } \\
\text { ext. }\end{array}$ & 330 & 0 & 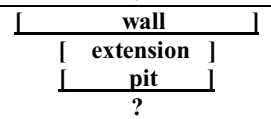 & 0 & 2 & 0 & 2 & 0 \\
\hline & & $\begin{array}{l}\text { great pillar } \\
\text { room, } \mathrm{S} \text { half } \\
\text { of } \mathrm{W} \text { wall }\end{array}$ & $7^{\text {th }}-8^{\text {th }} \mathrm{c} . \mathrm{AD}$ & 1 & 165 & $\begin{array}{l}90 \\
\text { incl. } \\
\text { ext. }\end{array}$ & 330 & 0 & 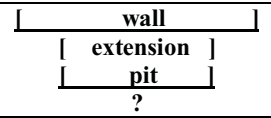 & 0 & 2 & 0 & 2 & 0 \\
\hline & & $\begin{array}{l}\text { great pillar } \\
\text { room, } \mathrm{N} \text { half } \\
\text { of } \mathrm{W} \text { wall }\end{array}$ & $7^{7^{\text {th }}-8^{\text {th }}} \mathrm{c} . \mathrm{AD}$ & 1 & 165 & $\begin{array}{c}90 \\
\text { incl. } \\
\text { ext. }\end{array}$ & 330 & 0 & $\begin{array}{c}\text { wall } \\
{\left[\begin{array}{c}\text { extension } \\
\text { pit }\end{array}\right]} \\
\frac{?}{?}\end{array}$ & 0 & 2 & 0 & $?$ & 0 \\
\hline \multirow{2}{*}{ 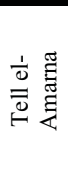 } & 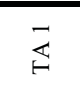 & $\begin{array}{l}\text { pillar hall, } \mathrm{E} \\
\text { wall, } \mathrm{N} \text { end }\end{array}$ & $\begin{array}{l}\text { 1st mill. AD: } \\
\text { Christian }\end{array}$ & 1 & $\begin{array}{l}276- \\
293\end{array}$ & $\begin{array}{l}14- \\
45\end{array}$ & $\begin{array}{c}36- \\
48\end{array}$ & 20 & $\begin{array}{l}\text { wall } \\
\frac{\text { pit }}{?}\end{array}$ & 0 & 0 & 0 & 0 & $?$ \\
\hline & $\underset{F}{\stackrel{N}{\leftrightarrows}}$ & $\begin{array}{l}\text { pillar hall, } \mathrm{E} \\
\text { wall, } \mathrm{N} \text { end }\end{array}$ & $\begin{array}{l}\text { 1st mill. AD: } \\
\text { Christian }\end{array}$ & 1?? & 300 & 60 & $>100$ & 20 & $\frac{\text { wall }}{\text { pit })}$ & 0 & 0 & 0 & 0 & 0 \\
\hline
\end{tabular}




\begin{tabular}{|c|c|c|c|c|c|c|c|c|c|c|c|c|c|c|}
\hline \multirow{2}{*}{\multicolumn{2}{|c|}{ location }} & \multirow{2}{*}{ position } & \multirow{2}{*}{ Dating } & \multirow{2}{*}{ no. } & \multirow{2}{*}{$\begin{array}{c}\mathrm{L} \\
(\mathrm{cm})\end{array}$} & \multirow{2}{*}{$\begin{array}{c}W \\
\text { (cm) }\end{array}$} & \multirow{2}{*}{$\begin{array}{c}\mathrm{D} \\
(\mathrm{cm})\end{array}$} & \multirow{2}{*}{$\begin{array}{l}\text { dist. from } \\
\text { wall (cm) }\end{array}$} & \multirow{2}{*}{ wall-pit-seat relation } & \multicolumn{5}{|c|}{ fixations } \\
\hline & & & & & & & & & & b & bh & tn & cs & \\
\hline & $\stackrel{m}{\stackrel{m}{\rightleftarrows}}$ & $\begin{array}{l}\text { longitudinal } \\
\text { hall, W wall, } \\
\text { S half }\end{array}$ & $\begin{array}{l}\text { 1st mill. AD: } \\
\text { Christian }\end{array}$ & 1 & 244 & 20 & 5 & 30 & $\frac{\text { wall }}{(\text { pit })}$ & 0 & $1 ?$ & 5 & 0 & 1 \\
\hline & 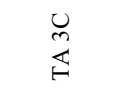 & $\begin{array}{l}\text { longitudinal } \\
\text { hall, W wall, } \\
\text { middle }\end{array}$ & $\begin{array}{l}\text { 1st mill. AD: } \\
\text { Christian }\end{array}$ & 1 & $\begin{array}{c}282- \\
293\end{array}$ & $\begin{array}{c}22- \\
30\end{array}$ & $\begin{array}{c}21- \\
40\end{array}$ & 30 & $\frac{L \text { wall }}{\frac{\text { pit }}{?}}$ & 0 & $1 ?$ & 2 & 0 & 1 \\
\hline & $\sum_{\models}^{\infty}$ & $\begin{array}{c}\text { forecourt, } \\
\text { 'Coptic } \\
\text { structures' in } \\
\text { W half, N } \\
\text { wall }\end{array}$ & $\begin{array}{l}\text { 1st mill. AD: } \\
\text { Christian }\end{array}$ & 1 & $\begin{array}{c}231- \\
268\end{array}$ & $\begin{array}{c}20- \\
33\end{array}$ & $\begin{array}{c}23- \\
30\end{array}$ & 65 & $\frac{L}{\text { wall }} \frac{\text { (stoneledge })}{\frac{(\text { pit })}{(\text { extension }) ?}}$ & 0 & $2 ?$ & 0 & 0 & 0 \\
\hline & \multirow{2}{*}{$\stackrel{Ð}{\uplus}$} & $\begin{array}{l}\text { forecourt, E } \\
\text { half, } \mathrm{N} \text { wall }\end{array}$ & $\begin{array}{l}\text { 1st mill. AD: } \\
\text { Christian }\end{array}$ & 1 & 284 & 20 & 13 & $30-40$ & $\frac{\text { wall }}{(\text { pit ) }}$ & 0 & 0 & 0 & 0 & 0 \\
\hline & & $\begin{array}{l}\text { first hall, E } \\
\text { wall, } \mathrm{N} \text { end }\end{array}$ & $\begin{array}{l}\text { 1st mill. AD: } \\
\text { Christian }\end{array}$ & 1 & $\begin{array}{c}257- \\
258\end{array}$ & $7-12$ & $\begin{array}{c}20- \\
25\end{array}$ & 80 & $\begin{array}{c}\text { wall } \\
? \\
\left(\begin{array}{c}\text { pit } \\
?\end{array}\right.\end{array}$ & 0 & 2 & 0 & 0 & 0 \\
\hline & $\stackrel{n}{\rightleftarrows}$ & $\begin{array}{l}\text { longitudinal } \\
\text { hall, } \mathrm{S} \text { side, } \\
\text { E end }\end{array}$ & $\begin{array}{l}\text { 1st mill. AD: } \\
\text { Christian }\end{array}$ & 1 & $\begin{array}{c}291- \\
298\end{array}$ & $\begin{array}{l}12- \\
21\end{array}$ & $\begin{array}{l}30- \\
38\end{array}$ & 40 & $\begin{array}{c}\text { wall } \\
\frac{\text { pit }}{?}\end{array}$ & 0 & $1 ?$ & 0 & 0 & 0 \\
\hline \multirow{2}{*}{ 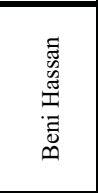 } & $\stackrel{m}{m}$ & $\begin{array}{l}\text { pillar hall, S } \\
\text { wall, middle }\end{array}$ & $1^{\text {st }}$ mill. AD? & $1 ? ?$ & 230 & 40 & 30 & 15 & $\begin{array}{c}\text { wall } \\
\text { pit } \\
?\end{array}$ & $?$ & $?$ & $?$ & $?$ & $?$ \\
\hline & 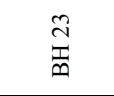 & $\begin{array}{l}\text { pillar hall, } \mathrm{N} \\
\text { wall, middle }\end{array}$ & $1^{\text {st }}$ mill. AD? & $1 ? ?$ & 195 & 38 & $?$ & 25 & $\frac{\text { wall }}{\text { (pit }}$ & $?$ & $?$ & $?$ & $?$ & $?$ \\
\hline \multirow{3}{*}{ 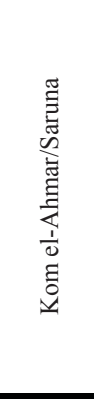 } & 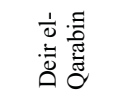 & $\begin{array}{l}\text { room } 10, \mathrm{E} \\
\text { wall }\end{array}$ & $\begin{array}{c}\text { till } 7^{\text {th }}-8^{\text {th }} \mathrm{c} \\
\text { AD }\end{array}$ & 1 & 350 & $\begin{array}{c}40- \\
55\end{array}$ & $\begin{array}{c}45- \\
50\end{array}$ & 40 & $\left.\begin{array}{lll}{[} & \text { wall } & \text { ] } \\
& (\text { pit }\end{array}\right)$ & 1 & 2 & 0 & 0 & 0 \\
\hline & \multirow{2}{*}{ 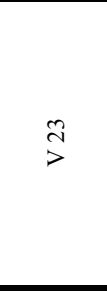 } & $\begin{array}{c}\text { forecourt, } \\
\text { 'Coptic } \\
\text { building' in } \\
\text { NE edge, } N \\
\text { wall }\end{array}$ & $\begin{array}{c}\text { till } 7^{\text {th }}-8^{\text {th }} \mathrm{c} \\
\text { AD }\end{array}$ & $1 ? ?$ & 320 & 40 & 30 & 20 & {$\left[\begin{array}{l}\text { wall } \\
\text { pit?? } \\
\text { seat }\end{array}\right)$} & 0 & 0 & 2 & 0 & 0 \\
\hline & & $\begin{array}{c}\text { forecourt, } \\
\text { 'Coptic } \\
\text { building' in } \\
\text { NE edge, W } \\
\text { wall }\end{array}$ & $\begin{array}{c}\text { till } 7^{\text {th }}-8^{\text {th }} \mathrm{c} \\
\text { AD }\end{array}$ & $1 ? ?$ & 360 & $\begin{array}{l}70- \\
75\end{array}$ & 45 & 0 & {$\left[\begin{array}{l}\text { wall } \\
\left(\begin{array}{l}\text { pit?? } \\
\text { seat }\end{array}\right)\end{array}\right.$} & 0 & 0 & 3 & 0 & 0 \\
\hline \multirow{2}{*}{ 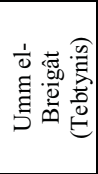 } & thesauros & $\begin{array}{l}\text { storage } \\
\text { room? }\end{array}$ & $\begin{array}{c}\text { late } \\
\text { Ptolemaic, } 2^{\text {nd }} \\
\text { c. BC } \\
\end{array}$ & $1 ? ?$ & 295 & 50 & $>70$ & $?$ & 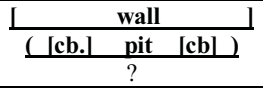 & 2 & 2 & $?$ & $?$ & $?$ \\
\hline & $?$ & $?$ & $\begin{array}{c}\text { late } \\
\text { Ptolemaic, } 2^{\text {nd }} \\
\text { c. BC }\end{array}$ & $1 ? ?$ & $?$ & $?$ & $?$ & $?$ & 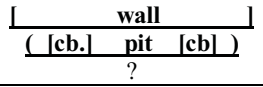 & $?$ & $?$ & $?$ & $?$ & $?$ \\
\hline
\end{tabular}




\section{Bibliography:}

Bács, T. (2000) “The so-called 'Monastery of Cyriacus' at Thebes”, Egyptian Archaeology, 17, p. 34-36.

Barber, E.J.W. (1991) Prehistoric Textiles. The Development of Cloth in the Neolithic and Bronze Ages with Special Reference to the Aegean, Princeton.

Bavay, L. (2007-2008) 'Dis au potier qu'il me fasse un kôtôn', Archéologie et céramique de l'Antiquité tardive à nos jours dans la TT 29 à Cheick Abd el-Gourna, Égypte, Université Libre de Bruxelles - unpubl. PhD-thesis.

Bechtold, E. (2007) "Reinterpretation of Coptic Looms Based on Material from TT 65", in K. Endeffry \& A. Gulcás (eds.), Proceedings of the fourth Central European Conference of Young Egyptologists 31 August - 2 September 2006 Budapest. Studia Aegyptiaca 18, Budapest, p. 51-62.

Beckh, Th. (2013) Zeitzeugen aus Ton. Die Gebrauchskeramik der Klosteranlage Deir el-Bachît in Theben-West (Oberägypten). Sonderschriften des Deutschen Archäologischen Instituts Abteilung Kairo 37, Berlin.

Boud'hors, A. \& Heurtel, C. (2002) "The Coptic Ostraca from the Tomb of Amenemope", Egyptian Archaeology 20, p. 7-9.

Broudy, E. (1979) The Book of Looms. A history of the handloom from Ancient times to the present, New York (reprinted in 1993 by the University Press of New England, Hanover -London).

Bruyère, B. (1948) Rapport sur les fouilles de Deir el Médineh (1935-1940). Fasc. I : Les fouilles et les découvertes de constructions. Fouilles de l'Institut français d'archéologie orientale du Caire 20/1, Cairo.

Carroll, D.L. (1985) "Dating the Foot-powered Loom: The Coptic Evidence”, American Journal of Archaeology 89, p. 168-173.

Carroll, D.L. (1988) Looms and Textiles of the Copts. Memoirs of the California Academy of Sciences 11, Seattle.

Castel, G. (1979) "Étude d'une momie copte", in J. Vercoutter (ed.), Hommages à la mémoire de Serge Sauneron 1927-1976 II: Égypte post-pharaonique. Bibliothèque d'Étude 82, Cairo, p. 121-143.

Castel, G. (1991) “Qurnet $\operatorname{Mar}^{c} 1$ ”, in A.S. Atiya (dir.), The Coptic Encyclopedia, vol. 7, New York, col. 2042-2043.

Crowfoot, G.M. (1941) "The Vertical Loom in Palestine and Syria”, Palestine Exploration Quarterly 73, p. 141-151.

Crum, W.E. \& Evelyn White, H.G. (1926) The Monastery of Epiphanius at Thebes, Part II. Publications of the Metropolitan Museum of Art, Egyptian Expedition 4, New York.

de Garis Davies, N. (1903) The Rock Tombs of El Amarna, Part I. Archaeological Survey of Egypt 13, London. de Garis Davies, N. (1905a) The Rock Tombs of El Amarna, Part II. Archaeological Survey of Egypt 14, London.

de Garis Davies, N. (1905b) The Rock Tombs of El Amarna, Part III. Archaeological Survey of Egypt 15, London.

de Garis Davies, N. (1906) The Rock Tombs of El Amarna, Part IV. Archaeological Survey of Egypt 16, London.

Eichner, I. Beckh, T. \& Sigl, J. (2009) "Das Kloster Deir el-Bachit in Theben-West”, in D. Kessler, R. Schulz, ... M. Goecke-Bauer (eds.), Texte-Theben-Tonfragmente, Festschrift für Günter Burkard. Ägypten und Altes Testament 76, Wiesbaden, p. 92-106.

el-Farag, R.A. (1983) "Excavation at Abydos in 1977", Mitteilungen des Deutschen Archäologischen Institut Abteilung Kairo 39, p. 51-57.

Gnirs, A.M., Grothe, E. \& Guksch, H. (1997) “Zweiter Vorbericht über die Aufnahme und Publikation von Gräbern der 18. Dynastie der thebanischen Beamtennekropole", Mitteilungen des Deutschen Archäologischen Institut Abteilung Kairo 53, p. 61-83.

Górecki, T. (2013) “The Hermitage in Sheikh Abd elGurna (Western Thebes): Excavation, Studies and Conservation in 2009 and 2010/2011", Polish Archaeology in the Mediterranean 22, p. 171-192.

Grimm, P. (1969) “The Royal Palace at Tilleda”, Medieval Archaeology 12, p. 83-10o.

Himmelmann, N. (1975) Das Hypogäum der Aurelier am Viale Manzoni, Wiesbaden.

Hölscher, U. (1934) The Excavations of Medinet Habu, Part I, Chicago.

Hölscher, U. (1954) The Excavations of Medinet Habu, Part $\mathrm{V}$, Chicago.

Huber, B. (2006) "Die Klosteranlage Deir el-Qarabin bei elKom el-Ahmar/Šaruna in Mittelägypten”, Bulletin de la Société d'Archéologie Copte 45, 2006, p. 59-68.

Huber, B. (2007) "Bautätigkeit und Wirtschaft in Deir elQarabin, Klosteranlage bei Kom el-Ahmar/Šaruna”, Bulletin de la Société d'Archéologie Copte 46, p. 61-68.

Kampp-Seyfried, F. (1995) Zur Konzeption doppelter Bestattungsanlagen. Studien zur Archäologie und Geschichte Altägyptens 12, Heidelberg.

Kemp, B.J. \& Vogelsang-Eastwood, G.M. (2001) The Ancient Textile Industry at Amarna. Egypt Exploration Society Excavation Memoir 68, London.

Makowiecka, E. (1986) "The Interpretation of Room 16 (Monastic Complex 14, Qusur el Izeila)”, in P. Bridel (ed.), Le site monastique copte des Kellia: sources historiques et explorations archéologiques. Actes du colloque de Genève 13 au 15 août 1984, Geneva, p. 107-112.

Makowiecka, E. (1999) “L'Ermitage QIZ 14”, in F. Bonnet Borel \& R. Kassel (dir.), Explorations aux Qouçoûr elIzeila lors des campagnes 1981, 1982, 1984, 1985, 1986, 
1989 et 1990. Mission Suisse d'archéologie copte de l'Université de Genève EK 8184, vol. 3, Leuven, p. 21-28. Messiha, H. \& Elhitta, M.A. (1979) Mallawi Antiquities Museum, Cairo.

Mossakowska-Gaubert, M. (2020) “A New Kind of Loom in Roman Egypt? How Iconography Could Explain (or not) Papyrological Evidence”, in M. Mossakowska-Gaubert (ed.), Egyptian Textiles and their Production: 'Word' and 'Object' (Hellenistic, Roman and Byzantine Periods). Zea Books 2020, Lincoln, p. 13-21. Available at: http:// digitalcommons.unl.edu/etpwo

Newberry, P.E. \& Fraser, G.W. (1893a) Beni Hasan, Part I. Archaeological Survey of Egypt 1, London.

Newberry, P.E. \& Fraser, G.W. (1893b) Beni Hasan, Part II. Archaeological Survey of Egypt 2, London.

Picton, J. \& Mack, J. (1979) African Textiles, London.

Roth, H.L. (1913) Ancient Egyptian and Greek Looms, Halifax.

Rzepka, S., Hudec, J. \& Herbich, T. (2008) "Tell el-Retaba 2008: Excavations and geophysical survey”, Polish Archaeology in the Mediterranean 20, p. 129-145.

Rzepka, S., Wodzińska, A., Hudec, J. \& Herbich, T. (2010) “Tell el-Retaba 2007-2008”, Ägypten und Levante 19, p. 241-280.

Schädler, K.-F. (1987) Die Weberei in Afrika südlich der Sahara, Munich.

Schenkel, W. \& Gomaà, F. (2004) Scharuna I, Mainz am Rhein.

Shedid, A. el-G. (1988) Stil der Grabmalereien in der Zeit Amenophis' II, Archäologische Veröffentlichungen. Deutsches Archäologisches Institut Abteilung Kairo 66, Mainz am Rhein.

Sigl, J. (2007) "Pits with Cross-Bars - Investigations on loom remains from Coptic Egypt", in K. Endreffy \& A. Gulyás (eds.), Proceedings of the Fourth Central European Conference of Young Egyptologists. Studia Aegyptiaca XVIII, Budapest, p. 357-372.

Sigl, J. (2008) "Koptische Webstuhlgruben in den Gräbern von Amarna?”, Studien zur altägyptischen Kultur 37, p. 355-361.

Sigl, J. (2011) "Weaving Copts in the North Tombs of Tell el-Amarna”, Studien zur altägyptischen Kultur 40, p. 357-386.

Sigl, J. (2016) "Looms in the Architecture of Monk. Dwellings from Coptic Egypt”, in L. Mahmoud \& A. Mansour (eds.), Copts in the Egyptian Society before and after Muslim Conquest. Studies in Calligraphy and Writings 19, Alexandria, p. 59-79.

Sigl, J. (2017) Syene II. Die Tierfunde aus den Grabungen von 2000 - 2009. Beiträge zur Ägyptischen Bauforschung und Altertumskunde 19, Gladbeck.

Sigl, J. \& Tatz, S., Dra Abu el-Naga 3. Deir
el-Bachît. Webstühle und Textilien. Archäologische Veröffentlichungen, Deutsches Archäologisches Institut Abteilung Kairo 130, Wiesbaden (in preparation).

Stærmose Nielsen, K.-H. (1999) Kirkes væv. Opstadvævens historie og nutidige brug. Forsøg med Fortiden 6, Lejre.

Strudwick, N. (2011) "Preserving the Old with the New: Priorities for Theban Tombs”, in G. A. Belova (ed.), Achievements and Problems of Modern Egyptology. Proceedings of the International Conference, September 29-October 2, 2009, Moscow, p. 370-385.

Tefnin, R.A. (2002) "A Coptic Workshop in a Pharaonic Tomb”, Egyptian Archaeology 20, p. 6.

Tietzel, B. (1988) Geschichte der Webkunst: Technische Grundlagen und künstlerische Traditionen, Cologne.

Valbelle, D. (1998) "Les garnisons de Migdol (Tell elHerr) de l'époque Achéménide au Bas-Empire: État de la question en 1998", Comptes Rendus à l'Académie des Inscriptions et Belles-Lettres I, p. 799-817.

Verhecken-Lammens, Chr. \& de Jonghe, D. (1993) "Weeftechnologisch Onderzoek van een Koptische Kindertuniek", Oudheidkundige Mededeelingen uit het Rijksmuseum van Oudheden te Leiden 73, p. 273-285.

von Blanckenhagen, P.H. (1940) Flavische Architektur und ihre Dekoration, Berlin.

von Pilgrim, C., Müller, W. \& Werlen, L. (2011) “The Town of Syene. Report on the 8th Season in Aswan", Mitteilungen des Deutschen Archäologischen Institut Abteilung Kairo 67, p. 125-162.

Walton Rogers, P. (2001) "The Re-appearance of the Old Roman Loom in Medieval England”, in L. Bender Jørgensen, A. Rast-Eicher \& P. Walton Rogers (eds.), The Roman Textile Industry and its Influence. A Birthday Tribute to John Peter Wild, Oxford, p. 158-171.

White, L.T. (1962) Medieval Technology and Social Change, Oxford.

Wild, J.P. (1987) “The Roman Horizontal Loom”, American Journal of Archaeology 91, p. 459-471.

Windler, R. (2008) "Mittelalterliche Webstühle und Weberwerkstätten - Archäologische Befunde und Funde", in W. Melzer (ed.), Archäologie und mittelalterliches Handwerk, Soest, p. 201-215.

Winlock, H.E. \& Crum, W.E. (1926) The Monastery of Epiphanius at Thebes, Part I. Publications of the Metropolitan Museum of Art, Egyptian Expedition 3, New York.

Winlock, H.E. (1955) Models of Daily Life in Ancient Egypt from the Tomb of Meket-rēe. Publications of the Metropolitan Museum of Art, Egyptian Expedition 18, Cambridge.

Zhao, K. (2001) Das Wissen der alten Chinesen, Düsseldorf. 